\title{
Engineering Site Investigation for Foundation Design and Construction in Shale and Sandstone Derived Soils of Okitipupa Area, Southwestern Nigeria
}

\author{
Falowo Olumuyiwa Olusola* \\ Department of Civil Engineering Technology, Faculty of Engineering Technology, Rufus Giwa Polytechnic, Owo, \\ Ondo State, Nigeria
}

\begin{abstract}
Geotechnical and geo-electrical investigations for engineering foundation studies were carried out at Okitipupa and environs, with the objectives of establishing the subsoil/geology; assessing the geotechnical properties, and provide appropriate foundation design parameters for building foundation construction, and investigating any geological hazard that could be inimical to foundation/basement construction. Borings in the form of shaft/trial pit were conducted at the exact points where cone penetration test was carried out, while a hand-auger sampling tool was used to collect representative samples. The samples were analyzed in the laboratory following relevant geotechnical engineering laboratory standards. In addition, six vertical electrical soundings (VES) were also conducted using the Schlumberger configuration. The VES delineated three distinct geologic layerings comprising the caprock, near-surface sand aquifer, and deep-seated sand aquifer. The topsoil/caprock had a resistivity range of 242-1503 ohm-m and thicknesses of 3.4-20.9 $\mathrm{m}$ and was composed of clay sand and sand. This layer supported shallow foundations such as simple spread, a raft of reinforced concrete, recommended allowable bearing pressure of $100 \mathrm{kN} / \mathrm{m}^{2}$ at depths of $1.0 \mathrm{~m}$ (northern area) and $3.2 \mathrm{~m}$ (southern part). The estimated settlement was less than $50 \mathrm{~mm}$ for a foundation design width of 0.6 $\mathrm{m}$ but could be reduced by almost $50 \%$ if the width is greater than or equal to $2 \mathrm{~m}$. The groundwater level was $10 \mathrm{~m}$ and might not likely affect the integrity of the foundation structures. The estimated allowable bearing capacity for strip footing $\left(203-980 \mathrm{kN} / \mathrm{m}^{2}\right)$ and square footing $\left(608-2940 \mathrm{kN} / \mathrm{m}^{2}\right)$ within $1.4 \mathrm{~m}$ depth was appropriate. The estimated pile capacity for driven circular piles using design diameters of $400 \mathrm{~mm}, 500 \mathrm{~mm}$, and 600 $\mathrm{mm}$ varied between $69-124 \mathrm{kN}$ at $5 \mathrm{~m}$ depth, $225-378 \mathrm{kN}$ at $10 \mathrm{~m}$ depth, and $470-766 \mathrm{kN}$ at $15 \mathrm{~m}$ depth; while that of bored circular pile ranged from $36-75 \mathrm{kN}, 93-180 \mathrm{kN}$, and 170 $317 \mathrm{kN}$ at depth levels of $5 \mathrm{~m}, 10 \mathrm{~m}$, and $15 \mathrm{~m}$ respectively. In other words, the bearing capacity of the piles increases with depth within the geological formations.
\end{abstract}

Keywords: Driven pile · Strip footing · Square footing · Geotechnical · Okitipupa.

\section{INTRODUCTION}

Most civil engineering structures rest on the soil surface, so these structures' lives depend upon the load-carrying capacity of soil (Das, 2004; Terzaghi and Peck, 1967). The bearing capac-

\footnotetext{
${ }^{*}$ Corresponding author: F.O. Olusola, Department of Civil Engineering Technology, Faculty of Engineering Technology, Rufus Giwa Polytechnic, Owo, Ondo State, Nigeria. E-mail: oluwanifemi.adeboye@yahoo.com
}

ity of a soil depends on the various properties of soil, which are determined by detailed soil studies/investigations. The detailed soil exploration program involves deep boring, field tests, and laboratory tests for delineating different soil properties. The purpose of soil exploration is to determine the basic properties of soil that affect the design of the structure's safety; determine the extent and properties of the material to 
be used for construction; to determine groundwater condition; to analyze the causes of failure of existing works (Murthy, 2002). Such investigations are used to decide the appropriate type of foundation and the soil suitability for construction. Sand and gravel are excellent foundation materials, unlike peat, plastic silt, and organic soil, associated with high compressibility. A foundation is required to transmit the load of the structure on a large area of soil. The structure's foundation should be designed so that the soil below does not fail in shear nor undergo excessive settlement (Bell, 2007; Tomlinson, 1999). The conventional foundation design method is based on the concept/theory of bearing capacity, which is also influenced by the foundation's width, shape, and depth. Hence important soil parameters or characteristics like shear strength, density, permeability must be studied holistically.

Consequently, engineering subsoil investigation was carried out in Okitipupa and environed in Southwestern Nigeria to provide geotechnical or geoelectrical parameters data. It would help select a proper type of foundation that would be cost-effective/economical; and recommended appropriate foundation design options, using conventional geophysical and geotechnical investigations. This would further assist the government in its infrastructural development strive in the State. Hence in-situ cone penetration testing combined with geophysical methods were employed to achieve the aim of this study. Geophysical techniques that can be used to determine bedrock depth include gravity, magnetic, resistivity, ground radar, seismic refraction, seismic reflection (Osinowo and Falufosi, 2018; Osinowo et al., 2011; Coker, 2015). It has also been shown that geophysical surveys are efficient and cost-effective in providing the required geotechnical information (Badmus et al., 2012; Coker et al., 2013; Ibitoye et al., 2013). The application of electrical resistivity has provided qualitative data in the hydrogeological investigation, natural hazards studies, environmental engineering site investigation, groundwater pollution studies, and subsurface mapping. Akintorinwa and Oluwole (2018), Adigun et al. (2014) have employed resistivity methods in mapping the distribution of electrical properties for hydrogeological and dam-site investigation. Their study demonstrated the ability of geophysical investigation to measure both subsurface physical parameters such as ground resistivity and determine the spatial variation of the measured parameter along with the three orthogonal directions. The geoelectrical generated sections, maps, and 3-D models of the subsurface provided relevant information that could guide point selection for geotechnical investigations and structural construction.

The CPT is a method of determining the in-situ mechanical properties of soils (Coerts, 1996). The test method has gained extensive preference over the years because of its rapid procedure, relatively cheap operational cost, and continuous reproducible results (Lunne et al., 1997; Nottingham, 1975; Mazlan, 2007). Following the standardization of the test process and improvement in data interpretation methods, its reliability is excellent. In most CPT measurements, the mobilized cone tip resistance is representative of the formation conditions. A semi-empirical method of interpretation of such data is available in many academic journals. The method was developed from a theoretical concept. The angle of internal friction, cohesion, and ultimate bearing capacity of soils can be directly obtained from observed tip resistance. The results of the interpretations are in good agreement with field conditions. The method is particularly suitable in cases where the accuracy of the measured skin friction is in doubt. CPT soundings can be very effective in site characterization, especially sites with discrete stratigraphic horizons or discontinuous lenses (Mazlan, 2007).

Consequently, the combination of geophysical and geotechnical methods in foundation investigation has shown to be invaluable in deciphering the depth to bedrock, characterizing the earth materials, and extent of variation of allowable bearing pressure of foundation soils (Ngah and Nwankwoala, 2013; Oyedele et al., 2011; Nwankwoala and Warmate, 2014). Geotechnical sampling along carefully selected points or varying geo-resistivity zones would provide relevant information for subsurface heterogeneity. Thus guide in the design analysis of appropriate foundation that will support every part of the building amidst possible varia- 
tion in rock strength (Nwankwoala and Amadi, 2013; Owamah et al., 2018; Sudha et al., 2009).

\section{Description of Study AREA}

The study location is one of the major cities in Ondo State, Southwestern Nigeria. It is located between Latitudes 704000 to $734000 \mathrm{mN}$ and Longitudes 682000 to $712000 \mathrm{mE}$ (Figure 1). The town lies within the tropical rainforest zone of West Africa. The climate is humid and semihot equatorial type. The city experiences heavy rainfall, with an average annual rainfall of 2000$2500 \mathrm{~mm} / \mathrm{yr}$, especially during the rainy seasons (April - October). The superficial rainfall distribution is bimodal, with peaks in July and September and a two-week break in August. The rainy season begins in March and lasts till October or early November. The higher annual rainfall depths and rainfall days encourage large volumes of runoff. However, variations occur in rainfall intensity from year to year, usually between 2,000 $\mathrm{mm}$ and 2,500 $\mathrm{mm}$ (Iloeje, 1981). Relative humidity alternates between $75 \%$ and $90 \%$ during the dry and rainy seasons. The area is regionally gently undulating southward; topographic elevations vary within a neighborhood of $120 \mathrm{~m}$ above the mean sea level in the northern part. The southern area is characterized by a low gradient with elevation generally less than $5 \mathrm{~m}$ above sea level (Omosuyi, 2001; Omosuyi et al., 2007) (Figure 2).

The basement rocks of southwestern Nigeria underlie the Okitipupa area in the northern part and sedimentary rocks in the south (Figures 3 and 4). The zone constitutes the easternmost segment of the extensive Dahomey basin. Many perennial streams and rivers drain the area; notable are Ominla, Oluwa, Akeun, Ufara, and Oni. The southern part is characterized by a lagoon, coastal creeks, canals, and several tributaries to the extensive river Oluwa. The annual temperature range from 24 to $27^{\circ} \mathrm{C}$, and the mean annual rainfall of over $2500 \mathrm{~mm}$ (Iloeje, 1981). The area is underlain by the coastal plain sands or Benin formation (Figure 3). The sediments of the coastal plain, deposited during the Late Tertiary-Early Quaternary period (Okosun, 1998; Omatsola and Adegoke, 1981; Jones and Hockey, 1964), consist of unconsolidated, coarse to medium-fine grained sands and clayey shale. The sands are generally mod-
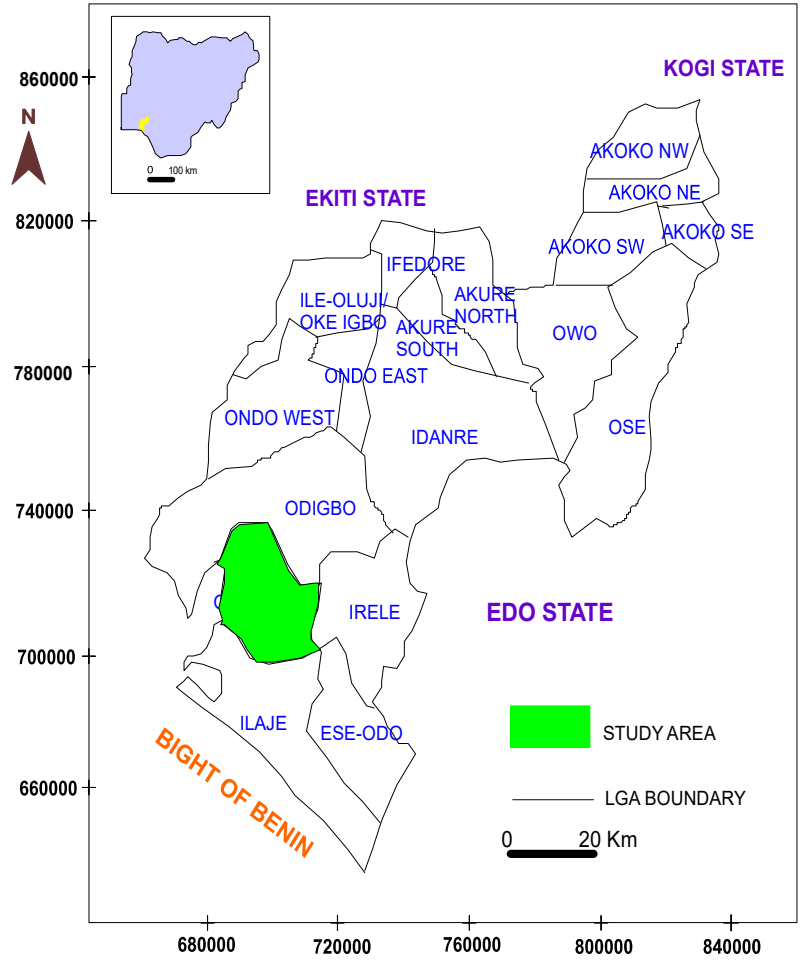

FIGURE 1. Location map of the study area.

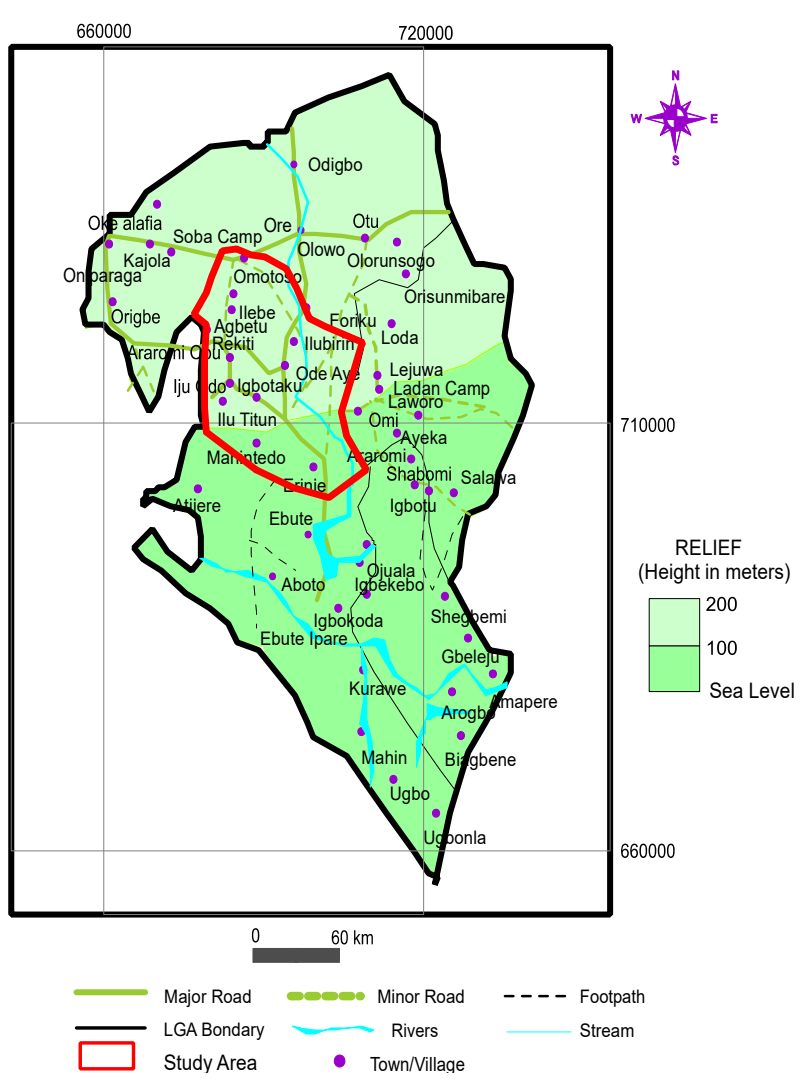

FIGURE 2. Surface relief map of the study area. 


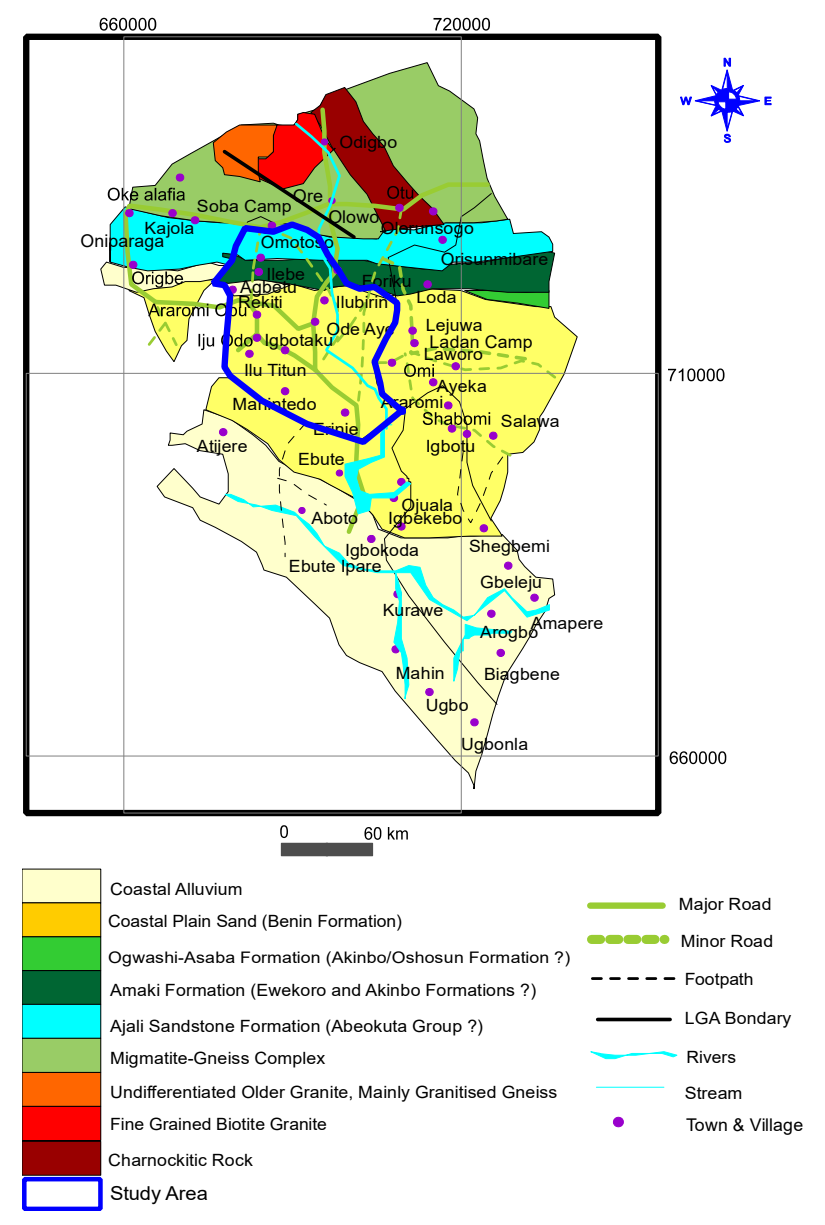

FIGURE 3. Geological map of the study area .

erately sorted and poorly cemented. The Benin Formation is overlain by lateritic overburden or recent alluvial deposits and underlain by Paleocene Akinbo Formation. This formation is predominantly shally. The Akinbo shale is underlain by the continental Cretaceous sediments of the Abeokuta Group (Omatsola and Adegoke, 1981). The coastal plain sands constitute the shallow hydrogeologic units in the area. Aquifers are characteristically continental sands, gravels, or marine sands. The lateritic earth overlying the sands and the underlying impervious clay/shale member of the Akinbo formation constitute a protective configuration for the aquifer units.

\section{Methodology}

The frequently used technique in engineering site investigation/foundation studies is the resistivity method. The resistivity of rock/soil is a function of the water filling the pore spaces (Telford et al., 1990). Thus, massive rocks such as granites are poor conductors (unless they are fractured). At the same time, gravels and clean sands have a relatively lower resistivity if filled with water, and sands saturated with saline water have the lowest resistivity values. Vertical electrical sounding using Schlumberger array involved measuring apparent resistivity of rocks and soil as a function of depth or position. The application of this method in geophysical prospecting involves measuring potential difference across two measuring electrodes when current flows through the subsurface between two current electrodes on a generalized four-electrode system of various configurations. The potential created can be from natural earth field/potential or created artificially by passing a direct electric current into the ground (Telford et al., 1990). Natural potentials are associated with oxidizing sulfide ores, corrosion of metals, the water of different chemical compositions in contact through pores, and other electrochemical sources. The electrical resistivity method employs artificial potentials that drop across two potentials electrodes in a fourelectrode system in determining the resistivity of the sub-surface formation. The resistivity of material can be defined as the resistance of conducting cylinder with a cross-sectional area $(A)$ and with a unit length $(L)$

$$
\begin{gathered}
\rho \propto \frac{A}{L} \\
\rho=\frac{R A}{L}
\end{gathered}
$$

Where $R$ = electrical resistance, $\rho=$ resistivity in ohm-meters. The electrode configuration used for this study is the Schlumberger array. Measurement of apparent resistivities is made by keeping the potential electrodes fixed about the mid-point of the array while the current electrodes are systematically spaced in opposite directions. As a result of its simplicity in interpretation and poor sensitivity to lateral variation of resistivity, it is used for vertical electrical sounding (VES). The instrument used is cable, steel electrodes, hammers, Ohmega resistivity meter, DC battery, Geographical positioning system, and measuring tapes. It involved moving the current electrodes and having the potential electrodes fixed about the cen- 


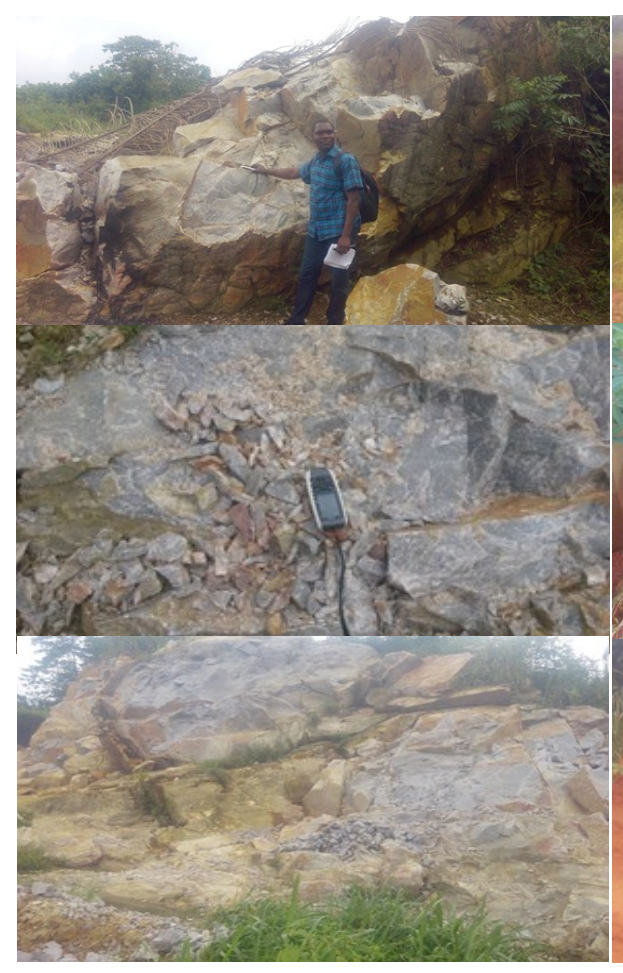

(a)

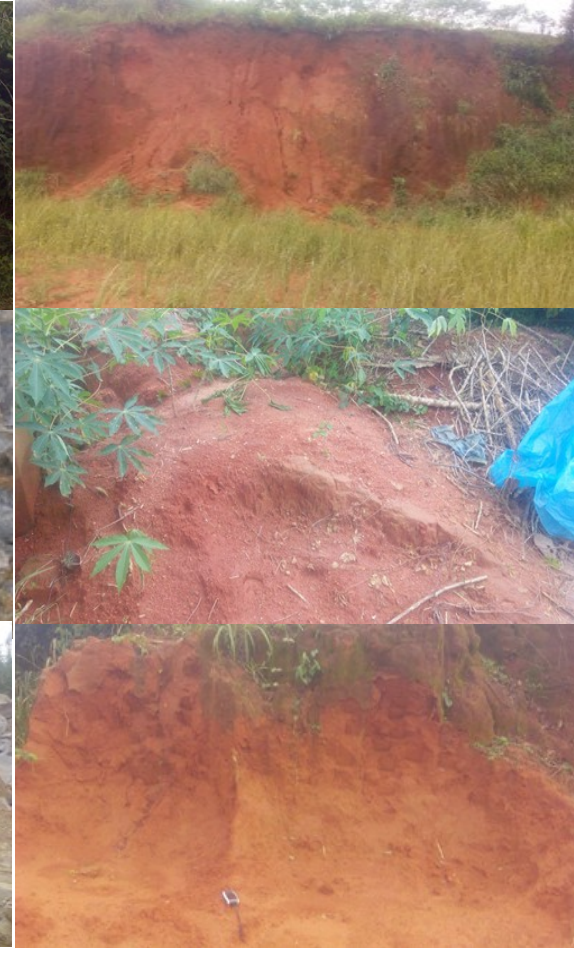

(b)

FIGURE 4. Field pictures of (a) migmatite gneiss and granitic rocks mapped in Ode Aye located at the northern part of the study area (b) soft shaly soil and mudstone observed along Okitipupa - Igbokoda highway at the southern part of the study area.

ter point. Six electrical soundings were carried out in the study area with maximum current electrode spacing $(\mathrm{AB})$ of $750 \mathrm{~m}$ on each VES points (Figure 5). Vertical Electrical Soundings (VES) were performed continuously, and the resistivity along a profile was measured. The data obtained were plotted on a bi-log graph, and the best smooth curve was taken through the set of data from the traditional method using master curves and auxiliary charts (Koefeod, 1979). The computer iteration technique refined the VES data. The model signature indicates low and high resistivity in the different layers encountered. The layer resistivity curves generated were interpreted quantitatively through partial curve matching techniques, which require the model curves.

The friction cone mechanical type penetrometer is for this study was Dutch Cone Penetrometer. It consists of a $60^{\circ}$ cone with a base diameter of $35.6 \mathrm{~mm}$ (sectional area $10 \mathrm{~cm}^{2}$ ). A sounding rod is screwed to the base. Additional rods of $1 \mathrm{~m}$ in length each are used. These rods are screwed or attached to bear against each other. The sounding rods move inside man-

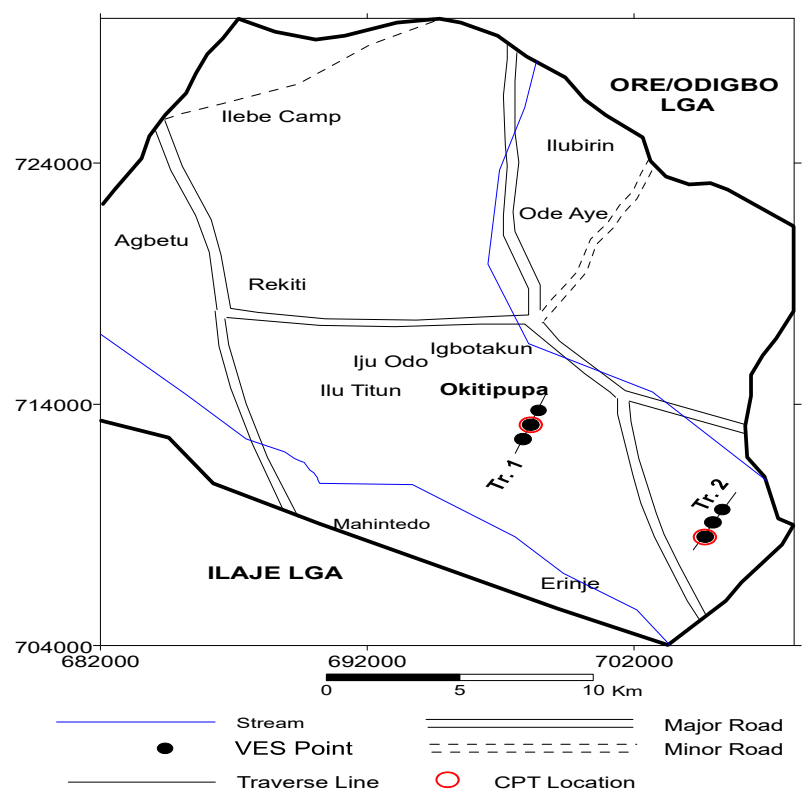

FIGURE 5. Base map of the study showing the study locations and field layout. 
TABLE 1. Soil classification based on friction ratio $\mathrm{Rf}$ (Sanglerat, 1972).

\begin{tabular}{cl}
\hline$R_{\mathrm{f}}(\%)$ & Type of Soils \\
\hline $0-0.5$ & Loose gravel fill \\
$0.5-2.0$ & Sands or gravels \\
$2.0-5.0$ & Clay sand mixture and silts \\
$>5.0$ & Clays, peats \\
\hline
\end{tabular}

tle tubes. The inside diameter of the mantle tube is sufficient for the sounding rods to move freely, whereas the outside diameter is equal to or less than the base diameter of the cone. One of the fundamental uses of CPT is to identify and classify soils. The classification is based on the friction ratio $f / q_{c}$ (Table 1). The ratio $f / q_{c}$ varies greatly depending on whether it applies to clays or sands. For clay soils, it has been found that the friction ratio decreases with increasing liquidity index. Therefore, the friction ratio is an indicator of the soil type penetrated. It permits approximate identification of soil type though no samples are recovered. Penetration rates were in between 10 to $20 \mathrm{~mm} / \mathrm{sec}$. Tests were performed in line with ASTM D 3441 (ASTM, 2006). The penetrometer data is plotted, showing the end-bearing resistance, the friction resistance, and the friction ratio (friction resistance divided by cone-bearing resistance) versus depth. Cone penetration resistance $\left(q_{c}\right)$ is obtained by dividing the total force Qc on the cone by the cone's base area " $A$ ". The interpreted result was presented in tabular form. The friction ratio plot can be analyzed to determine soil type. Many correlations of the cone test results to other soil parameters have been made, and design methods are available for spread footings and piles. The penetrometer can be used in sands or clays but not in rock or other highly dense soils.

The layer sequences were interpreted from the variation of the values of the cone resistance with depth. The allowable bearing pressure of the soil layers on each location was calculated using Meyerhof (1976) and Schmertmann (1978) equations direct method for estimating ultimate bearing capacity (qult) from cone resistance for square and strip footings, as follows

$$
q_{u l t}=q_{c}\left(\frac{B}{12.2}\right)\left(1+\frac{D_{f}}{B}\right)
$$

where,

$q_{c}=$ cone resistance value

$D_{f}=$ Depth of footing

$B=$ Width of foundation

For this study, the factor of safety of 3 was adopted to obtain the allowable bearing pressure.

For cohensionless soils (in $\left.\mathrm{kg} / \mathrm{cm}^{2}\right)$ :

Strip $q_{u l t}=28-0.0052\left(300-q_{c}\right)^{1.5}$

Square $q_{\text {ult }}=48-0.0052\left(300-q_{c}\right)^{1.5}$

For clay (in $\left.\mathrm{kg} / \mathrm{cm}^{2}\right)$ :

Strip $q_{u l t}=2+0.28 q_{c}$

Square $q_{u l t}=5+0.34 q_{c}$

All samples obtained in the field through hand auger were carefully preserved and subjected to more detailed visual inspection and descriptions at the laboratory. Subsequently, representative samples were selected from each stratum for laboratory analysis in line with relevant geotechnical engineering standards, including BS 1377 (BSI, 1990). The disturbed soil samples were appropriately subjected to the following laboratory classification tests: natural moisture content, Atterberg limits (liquid and plastic limits), grain size analysis, and unconsolidated undrained triaxial tests at different cell pressures. Sieve analysis of cohesive soils was done by soaking oven-dried samples in water overnight and washing through sieve No. 200 (75 microns opening), while remnants retained on sieve No. 200 were oven-dried and sieved mechanically. Materials finer than sieve number 200 were analyzed using the hydrometer method based on Stoke's Law.

Total consolidation settlement (s) has been computed for foundation breadth (B) between $0.5-3.0 \mathrm{~m}$, subjected to an allowable bearing capacity of $100 \mathrm{kN} / \mathrm{m}^{2}$. The induced vertical stress $(\Delta \sigma)$ at the center of the consolidating layer has been used in computing " $s$ ". The consolidation settlement has been computed from the expression below (Stroud and Butler, 1975):

$$
s=m_{v} H \Delta \sigma
$$

where, 
$m_{v}=$ coefficient of volume compressibility

$H=$ thickness of the compressible layer

$\Delta \sigma=$ average increase inadequate pressure

An $m_{v}$ value of $0.125 \mathrm{~m}^{2} / \mathrm{KN}$, which corresponds to the adopted net allowable bearing pressure, was used in the settlement analysis and corresponded to stiff clay in the range of $\left(0.25-0.125 \mathrm{~m}^{2} / \mathrm{KN}\right)$. The settlement analysis of the granular soil is determined using the Schmertmann equation (Schmertmann, 1970);

$$
\delta=C_{1} C_{2} C_{3} q^{\prime} \sum \frac{I_{e} \Delta z}{E_{s}}
$$

where;

$C_{1}=$ depth factor

$C_{2}=$ secondary creep factor

$C_{3}=$ shape factor

$q^{\prime}=$ net bearing pressure

$I_{e}=$ strain influence factor

$\Delta z=$ thickness of soil layer (at midpoint of soil layer)

$E_{S}=$ equivalent modulus of elasticity

Empirical correction for depth of embedment, secondary creep, and footing shape:

$$
\begin{gathered}
C_{1}=1-0.5\left[\frac{\sigma_{z D}^{\prime}}{q^{\prime}}\right] \\
C_{2}=1+0.2 \log \left(\frac{t}{0.1}\right) \\
C_{3}=1.03-0.03 \frac{L}{B} \geq 0.73
\end{gathered}
$$

In order to use the Schmertmann (1970) method, it is necessary to estimate the stiffness of the soil in terms of the equivalent Young's modulus at various depths. In the case of normally loaded cohesionless materials (not prestressed significantly to pressures above the present in in-situ overburden pressure, the CPT bearing capacity qc has been correlated with Young's modulus (Es) by DeBeer (1963) and Webb (1969). The relationship suggested by Schmertmann (1970) is

$$
E_{s}=2 q_{c}
$$

where $q_{c}=\mathrm{CPT}$ bearing capacity

Using Meyerhof equation (Meyerhof, 1976), the allowable and ultimate bearing capacity was calculated using this equation:

$$
\begin{aligned}
& q_{a}=2.7 q_{c}\left(\frac{K N}{m^{2}}\right) \\
& q_{a}=\frac{q_{c}}{40}\left(\mathrm{~kg} / \mathrm{cm}^{2}\right)
\end{aligned}
$$

For this study, the CFEM equation (CFEM, 1992) was used for modulus of elasticity determination. A modified version of the Terzaghi bearing capacity equation is widely used for pile design. The third term, or the density term, in the Terzaghi bearing capacity equation, is negligible in piles and hence usually ignored (CFEM, 1992; de Ruiter and Beringen, 1979; Bustamante and Gianeselli, 1982). The lateral earth pressure coefficient, $\mathrm{K}$, is introduced to compute the skin friction of piles.

$P_{\text {ultimate }}=\left(\sigma_{t}^{\prime} \times N_{q} \times A\right)+\left(K+\sigma_{v}^{\prime} \times \tan \delta \times A_{p}\right)$

where,

$P_{\text {ultimate }}=$ ultimate pile capacity

$\sigma_{t}^{\prime}=$ effective stress at the tip of the pile

$N_{q}$ = bearing factor cross-sectional area coefficient

$A=$ of the pile at the tip

$K$ = lateral earth pressure coefficient

$\sigma_{v}^{\prime}=$ effective stress at the perimeter of the pile

$\tan \delta=$ friction angle between pile and soil

$A_{p}=$ perimeter area of the pile

For round piles, $A_{p}=\pi d L$

where,

$d$ = diameter

$L=$ length of the pile

The API method (American Petroleum Institute) (API, 1984) uses the following equation for end-bearing capacity, adopted for this study. where, 
$q=N_{q} \times \sigma_{t}^{\prime} \times A$

$q$ is end bearing capacity of the pile

$\sigma_{t}^{\prime}$ is effective stress at the pile tip

A is the cross-sectional area of the (circular) pile at the tip $=\pi \times \frac{D^{2}}{4} ; D$ is the pile diameter.

The maximum effective stress used in the computation is within the $240 \mathrm{kPa}$ recommended (Meyerhof, 1976). The value of $\mathrm{Nq}$ depends on the soil:

$N_{q}=8$ to 12 for loose sand

$N_{q}=12$ to 40 for medium dense sand

$N_{q}=40$ for dense sand

Meyerhof (1976) suggested the following equation for driven/bored piles:

$$
s=\beta \times \sigma_{v}^{\prime} \times A_{p}
$$

where

$s=$ skin friction of the pile

$\sigma_{v}^{\prime}=$ effective stress at the midpoint of the pile

$A_{p}=$ perimeter surface area of the pile

For driven piles $\beta=0.44$ for $\varnothing=28^{\circ} ; \beta=0.75$ for $\varnothing=35^{\circ} ; \beta=1.2$ for $\varnothing=37^{\circ}$. For bored piles $\beta$ $=0.10$ for $\varnothing=33^{\circ} ; \beta=0.20$ for $\varnothing=35^{\circ} ; \beta=0.35$ for $\varnothing=37^{\circ}$.

\section{RESUlTS AND DisCUSSION}

Along Traverse 1, the geoelectric section (Figure 6) delineates a maximum of three geologic subsurface sequences consisting of the topsoil/caprock, which varies in composition from clayey sand to sand with resistivity value 242 to $1503 \mathrm{ohm}-\mathrm{m}$ and thickness that varies from $9.2-20.9 \mathrm{~m}$. This topsoil overlies a thick sand formation in most places in the area, the surficial aquifer unit. It is characterized by resistivity values that range from 58 to $5111 \mathrm{ohm}-$ $\mathrm{m}$ and a thickness of $15-70.1 \mathrm{~m}$. Beneath this layer is the intermediate aquifer with resistivity varying from $15-531 \mathrm{ohm}-\mathrm{m}$. The depth of this aquiferous unit ranges from 49.3 to $94.3 \mathrm{~m}$.

Consequently, the area's overburdened thickness is thick enough to distribute the structural load to the subsoil with moderate resistivity.
The presence of groundwater in the soil pores has a significant impact on the engineering behavior or characteristics of the soil, where deep excavation is to be carried out. The groundwater level along this traverse was measured during the CPT survey under VES 1 records value of $0.6 \mathrm{~m}$, which belief to be connate water trapped during the sedimentation or lithification process.

The geoelectric section along Traverse 2 (Figure 7) also showed three distinct subsurface layering, comprising the topsoil/caprock, sand (surficial aquifer), and sand (intermediate aquifer). The topsoil has resistivity varying from $84-1122 \mathrm{ohm}-\mathrm{m}$ and thickness of $3.4-$ $10.6 \mathrm{~m}$, composed of sandy clay, clayey sand, and sand. The near-surface and aquifer underlying the topsoil sand are characterized with resistivity values varying from $535-921 \mathrm{ohm}-$ $\mathrm{m}$ and thickness variation of $27.9-30.3 \mathrm{~m}$. The deep-seated (intermediate) system is the primary aquifer system characterized by resistivity in the range of $298-1333 \mathrm{ohm}-\mathrm{m}$. The depth of this geologic unit ranges from 30.2 to $45.8 \mathrm{~m}$. The existing borehole/well records groundwater level of $5-13 \mathrm{~m}$, measured when the rainfall intensity was high. Therefore, this depth may not seriously affect the bases of the foundation footing in the area (Bowles, 1988; Skempton, 1951). Hence the topsoil is competent (judging from resistivity and thickness values) to support the foundation structure along this traverse.

Tables 2 and 3 show the summary of the geotechnical results. The sand varies between $43.6-69.2 \%$, silt varies from $5.7-22.2 \%$, and clay ranges from $9.3-47.3 \%$. Generally, the soil is dominated by sandy clay (SC) and sandy silt (SM). The average clay content in the soil is less than $20 \%$ which falls within $35 \%$ recommended for subsoil material good for civil engineering foundation construction. The specific gravity of the soil recorded values in the range of 2.64 (sand) - 2.68 (clay). The engineering parameters of the soil samples are within the federal ministry of works and housing (FMWH, 1972) specification for civil engineering building foundation construction. The analyzed soil samples at both locations show liquid limits of $30.2-48.5$ $\%$ (within recommended 50\%), plastic limits of $19.5-28.5 \%$ (within recommended $30 \%$ ), plas- 


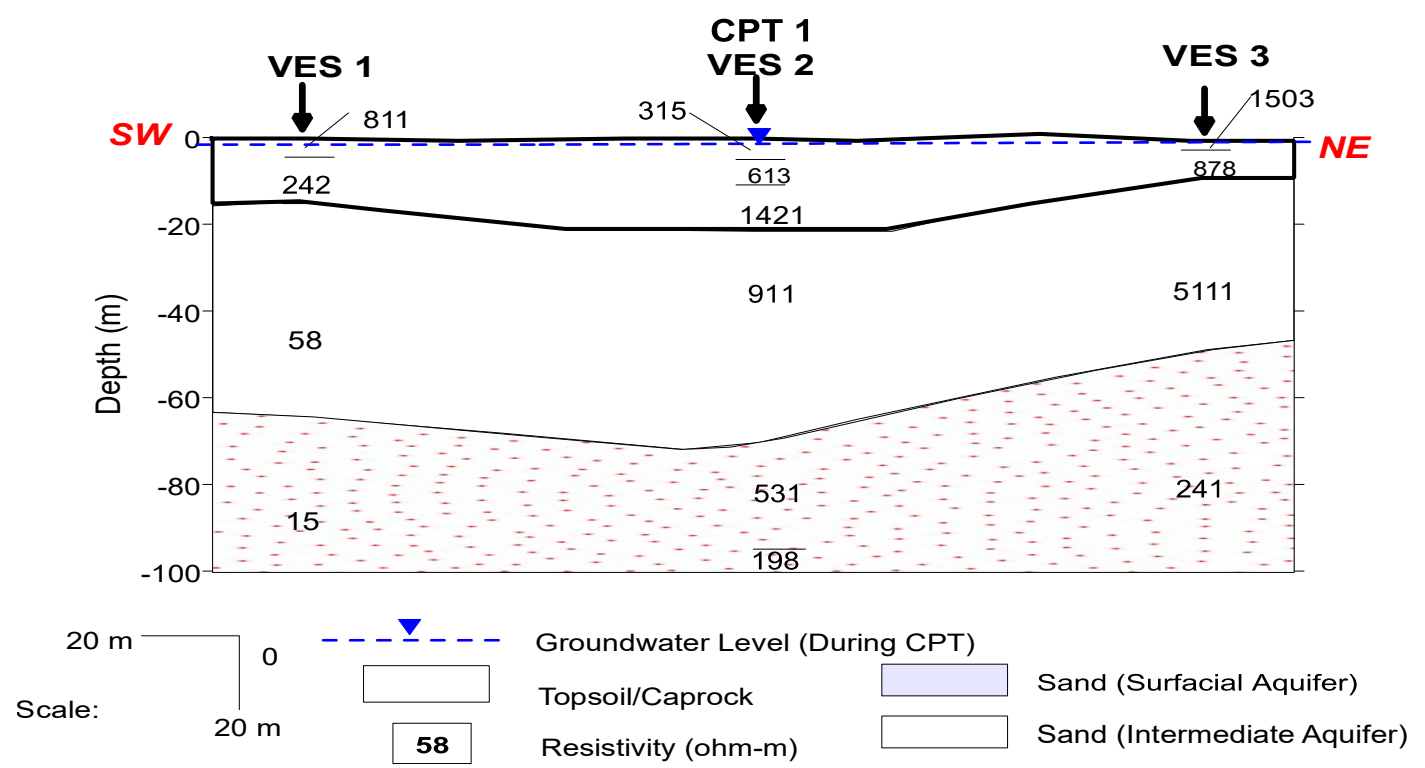

FIGURE 6. Geoelectric section along Traverse 1 in OSUTECH area.

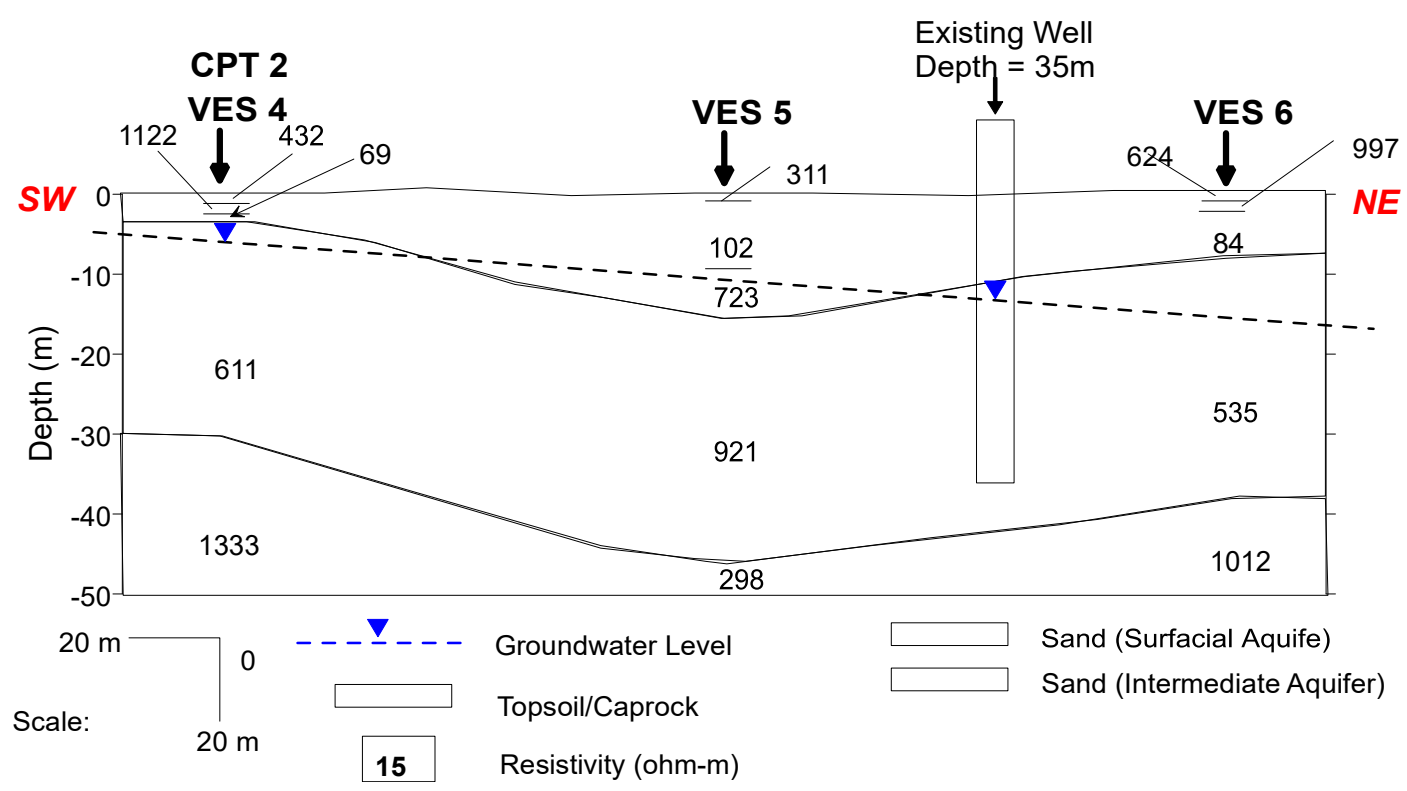

FIGURE 7. Geoelectric section along Traverse 2 established along Okitipupa/Igbokoda highway. 
ticity index of $10.6-21.1 \%$ (still within recommended 20\%), and shrinkage limits of $4.3-9.1$ $\%$ (indicating excellent/good soil quality). Generally, the lower the linear shrinkage value, the lesser the tendency to shrink when desiccated (Jegede, 2000). The natural moisture content ranges from $11.1-16.2 \%$, which is moderately low. However, location 1 shows better geotechnical properties than location 1, even though they show some overlapping values in their geotechnical properties. All the soil samples fall within the FMWH (1972) recommended standard for foundation material. Hence, the soil can be adjudged as good foundation soil.

The result of cone resistance with depth shows an increase in cone resistance and sleeve resistance with depth, ranging from $35-75$ $\mathrm{kg} / \mathrm{cm}^{2}$ and $50-101 \mathrm{~kg} / \mathrm{cm}^{2}$ at CPT 1 , and $5-$ $60 \mathrm{~kg} / \mathrm{cm}^{2}$ and $10-80 \mathrm{~kg} / \mathrm{cm}^{2}$ at CPT 2 , respectively. The friction ratio ranges from $1.23-1.58$ (CPT 1) and $1.00-2.20$ (CPT 2). The Robertson soil chart classification (Robertson, 1990) shows two dominant zones of 6 to 7 corresponding to sandy silt to clayey silt and silty sand to sandy silt (Figure 8). The plots of cone resistance and sleeve resistance against depth (Figure 9) showed a geological succession of sandy silt to clayey silt $(0-0.2 \mathrm{~m})$ and silty sand to sandy silt $(0.2-1.0 \mathrm{~m})$ at CPT 1 and four geologic layerings in CPT 2 , namely clay $(0-0.2 \mathrm{~m})$, silty sand to sandy silt $(0.2-2.8 \mathrm{~m})$, sand silt to clayey silt $(2.8-3.0 \mathrm{~m})$ and silty sand to sandy silt $(3.0-$ $4.0 \mathrm{~m})$. Consequently, at least a depth of $0.5 \mathrm{~m}$ and $3 \mathrm{~m}$ would be appropriate as a founding depth for designing and constructing shallow foundations and bases in the area.

The ultimate and allowable bearing capacity estimated from the cone resistance is presented in Table 4. The calculated bearing capacities could be used in determining the foundation type for structures. The allowable bearing of the soil varies between 86 to $184 \mathrm{kN} / \mathrm{m}^{2}$ for CPT 1 and $12-147 \mathrm{kN} / \mathrm{m}^{2}$ for CPT 2, while the ultimate bearing capacity of the soil ranged from 257 to $551 \mathrm{kN} / \mathrm{m}^{2}$ and 37 to $441 \mathrm{kN} / \mathrm{m}^{2}$, respectively. Hence an average allowable bearing capacity of $100 \mathrm{kN} / \mathrm{m}^{2}$ (ultimate bearing capacity of $300 \mathrm{kN} / \mathrm{m}^{2}$ ) would be appropriate for designing a shallow foundation in the area, at a depth not less than $0.4 \mathrm{~m}$ in locations 1 and $3.4 \mathrm{~m}$ at location 2 . Settlement and bear- ing capacity are the major factors that govern foundation design. The commonly accepted design basis is that the total settlement of a footing should be restricted to about $25 \mathrm{~mm}$ (Bell, 2007; Mazlan, 2007). By so doing, the differential settlement between adjacent footings is confined within limits that a structure can tolerate. The settlement analysis for foundation width of $0.6-3.0 \mathrm{~m}$ at three depth levels of $1 \mathrm{~m}$, $2 \mathrm{~m}$, and $3 \mathrm{~m}$ produced relatively high values greater than $25 \mathrm{~mm}$, i.e., $30.06-45.92 \mathrm{~mm}$ settlement values (Table 5). Although from the result, foundation width above $2.0 \mathrm{~m}$ produced settlement values less than $25 \mathrm{~mm}$ (Table 5) recommended by Bell (Mazlan, 2007) as it ranged between $10.70-17.28 \mathrm{~mm}$. These settlement values are still tolerable, as they are within Meyerhof (1976), Schmertamnn (1978) total settlement limits of $60 \mathrm{~mm}$ (clay) and $50 \mathrm{~mm}$ (granular soil). Therefore foundation width not less than $0.6 \mathrm{~m}$ for depth not less than $1 \mathrm{~m}$ is feasible. The calculation of bearing capacities for strip and square foundation is shown in Table 6. For strip foundation, the appropriate (recommended) ultimate bearing and allowable bearing capacity for depth levels of $0.6-1.4 \mathrm{~m}$ vary from $608-$ $2940 \mathrm{kN} / \mathrm{m}^{2}$ and $203-980 \mathrm{kN} / \mathrm{m}^{2}$, while square footing varies in between $990-3822 \mathrm{kN} / \mathrm{m}^{2}$ and 330 - $1274 \mathrm{kN} / \mathrm{m}^{2}$, respectively (Table 6).

An attempt was made to design for a deep foundation at depth levels of $5 \mathrm{~m}, 10 \mathrm{~m}$, and 15 $\mathrm{m}$ for circular piles of $400 \mathrm{~mm}, 500 \mathrm{~mm}$, and 600 $\mathrm{mm}$ while considering the groundwater level. The type of piles designed for in the area included driven/displacement piles and bored piles. The versatility and cost-effectiveness are part of the governing factors considered. The bearing capacity of the pile depends on pile diameter, founding depth, vertical stress, area of the pile, method of installation. The result (Table 7) shows that the larger the diameter of the pile, the better its bearing capacity. For driven piles at $5 \mathrm{~m}, 10 \mathrm{~m}$, and $15 \mathrm{~m}$, the adopted allowable capacity based on estimated calculation was between $69-124 \mathrm{kN}, 225-378 \mathrm{kN}$, and 470 - $766 \mathrm{kN}$, respectively. The allowable bearing capacity for bored piles ranges from $36-75 \mathrm{kN}$, $93-180 \mathrm{kN}$, and $170-317 \mathrm{kN}$ at depth levels of $5 \mathrm{~m}, 10 \mathrm{~m}$, and $15 \mathrm{~m}$, respectively (Table 7). Although it is recommended that pile load tests be conducted before the design, construction, and 


\section{OLUSOLA}

TABLE 2. Geotechnical/engineering properties of soil in location 1.

\begin{tabular}{cccccccccccccc}
\hline $\begin{array}{c}\text { Depth } \\
(\mathrm{m})\end{array}$ & $\begin{array}{c}\mathrm{Qc} \\
\left(\mathrm{kg} / \mathrm{cm}^{2}\right)\end{array}$ & $\begin{array}{c}\mathrm{SR} \\
\left(\mathrm{kg} / \mathrm{cm}^{2}\right)\end{array}$ & $\mathrm{R}_{\mathrm{f}}$ & $\begin{array}{c}\mathrm{LL} \\
(\%)\end{array}$ & $\begin{array}{c}\mathrm{PL} \\
(\%)\end{array}$ & $\begin{array}{c}\text { PI } \\
(\%)\end{array}$ & $\begin{array}{c}\text { LS } \\
(\%)\end{array}$ & $\begin{array}{c}\text { MC } \\
(\%)\end{array}$ & $\begin{array}{c}\text { Gravel } \\
(\%)\end{array}$ & $\begin{array}{c}\text { Sand } \\
(\%)\end{array}$ & $\begin{array}{c}\text { Silt } \\
(\%)\end{array}$ & $\begin{array}{c}\text { Clay } \\
(\%)\end{array}$ & SG \\
\hline 0.2 & 35 & 50 & 1.43 & 30.2 & 19.5 & 10.7 & 4.3 & 14.1 & - & 53.1 & 5.7 & 47.3 & 2.64 \\
0.4 & 48 & 60 & 1.25 & & & & & & & & & & \\
0.6 & 65 & 80 & 1.23 & 32.3 & 21.7 & 10.6 & 4.3 & 15.1 & - & 43.6 & 20.8 & 35.6 & 2.66 \\
0.8 & 60 & 95 & 1.58 & & & & & & & & & & \\
1.0 & 75 & 101 & 1.34 & 33.4 & 21.8 & 11.6 & 5.0 & 15.9 & - & 44.9 & 22.2 & 32.9 & 2.67 \\
\hline
\end{tabular}

TABLE 3. Geotechnical/engineering properties of soil in location 2.

\begin{tabular}{cccccccccccccc}
\hline $\begin{array}{c}\text { Depth } \\
(\mathrm{m})\end{array}$ & $\begin{array}{c}\mathrm{Qc} \\
\left(\mathrm{kg} / \mathrm{cm}^{2}\right)\end{array}$ & $\begin{array}{c}\mathrm{SR} \\
\left(\mathrm{kg} / \mathrm{cm}^{2}\right)\end{array}$ & $\mathrm{R}_{\mathrm{f}}$ & $\begin{array}{c}\text { LL } \\
(\%)\end{array}$ & $\begin{array}{c}\mathrm{PL} \\
(\%)\end{array}$ & $\begin{array}{c}\text { PI } \\
(\%)\end{array}$ & $\begin{array}{c}\text { LS } \\
(\%)\end{array}$ & $\begin{array}{c}\mathrm{MC} \\
(\%)\end{array}$ & $\begin{array}{c}\text { Gravel } \\
(\%)\end{array}$ & $\begin{array}{c}\text { Sand } \\
(\%)\end{array}$ & $\begin{array}{c}\text { Silt } \\
(\%)\end{array}$ & $\begin{array}{c}\text { Clay } \\
(\%)\end{array}$ & SG \\
\hline 0.2 & 5 & 10 & 2.2 & & & & & & & & & & \\
0.4 & 20 & 22 & 1.1 & & & & & & & & & & \\
0.6 & 20 & 25 & 1.25 & 43.5 & 22.4 & 21.1 & 9.1 & 16.2 & - & 68.5 & 20.1 & 11.4 & 2.67 \\
0.8 & 20 & 20 & 1 & & & & & & & & & & \\
1.0 & 15 & 20 & 1.33 & 41.2 & 24.4 & 16.8 & 8.6 & 11.1 & - & 69.2 & 21.5 & 9.3 & 2.67 \\
1.2 & 18 & 20 & 1.11 & & & & & & & & & & \\
1.4 & 12 & 25 & 2.08 & & & & & & & & & & \\
1.6 & 15 & 20 & 1.33 & & & & & & & & & & \\
1.8 & 15 & 20 & 1.33 & & & & & & & & & & \\
2.0 & 25 & 30 & 1.2 & 45.4 & 28.5 & 16.9 & 8.9 & 15.8 & - & 68.2 & 21.8 & 10 & 2.69 \\
2.2 & 30 & 35 & 1.17 & & & & & & & & & & \\
2.4 & 30 & 32 & 1.07 & & & & & & & & & & \\
2.6 & 35 & 40 & 1.14 & & & & & & & & & & \\
2.8 & 40 & 45 & 1.13 & & & & & & & & & \\
3.0 & 38 & 42 & 1.11 & 48.2 & 27.8 & 20.4 & 8.7 & 15.2 & - & 54.9 & 15.3 & 29.8 & 2.68 \\
3.2 & 40 & 50 & 1.25 & & & & & & & & & & \\
3.4 & 45 & 55 & 1.22 & & & & & & & & & & \\
3.6 & 50 & 65 & 1.3 & & & & & & & & & & \\
3.8 & 52 & 70 & 1.35 & & & & & & & & & \\
4.0 & 60 & 80 & 1.33 & 48.5 & 28.2 & 20.3 & 8.2 & 15.5 & - & 52.2 & 18.5 & 29.3 & 2.69 \\
\hline
\end{tabular}

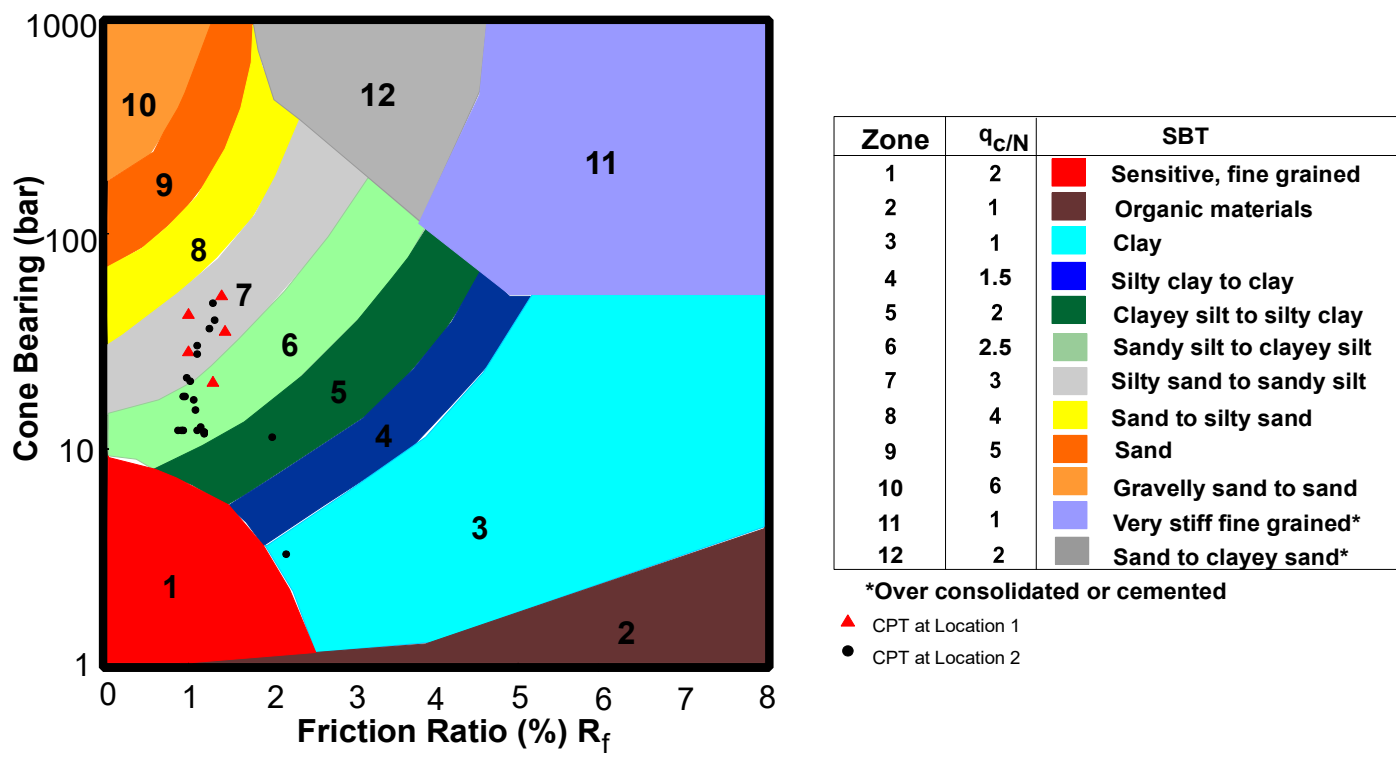

FIGURE 8. Robertson chart for the soil classification using cone resistance values and friction ratio. 
TABLE 4. The bearing capacity estimated from CPT obtained at different depths in the studied site.

\begin{tabular}{ccccc}
\hline \multirow{2}{*}{$\begin{array}{l}\text { Depth } \\
(\mathrm{m})\end{array}$} & \multicolumn{2}{c}{ CPT 1 } & \multicolumn{2}{c}{ CPT 2 } \\
\cline { 2 - 5 } & $\begin{array}{c}q_{\text {allowable }} \\
\left(\mathrm{kN} / \mathrm{m}^{2}\right)\end{array}$ & $\begin{array}{c}q_{\text {ultimate }} \\
\left(\mathrm{kN} / \mathrm{m}^{2}\right)\end{array}$ & $\begin{array}{c}q_{\text {allowable }} \\
\left(\mathrm{kN} / \mathrm{m}^{2}\right)\end{array}$ & $\begin{array}{c}q_{\text {ultimate }} \\
\left(\mathrm{kN} / \mathrm{m}^{2}\right)\end{array}$ \\
\hline 0.2 & 86 & 257 & 12 & 37 \\
0.4 & 118 & 353 & 49 & 147 \\
0.6 & 159 & 478 & 49 & 147 \\
0.8 & 147 & 441 & 49 & 147 \\
1.0 & 184 & 551 & 37 & 110 \\
1.2 & - & - & 44 & 132 \\
1.4 & - & - & 29 & 88 \\
1.6 & - & - & 37 & 110 \\
1.8 & - & - & 37 & 110 \\
2.0 & - & - & 61 & 184 \\
2.2 & - & - & 74 & 221 \\
2.4 & - & - & 74 & 221 \\
2.6 & - & - & 86 & 257 \\
2.8 & - & - & 98 & 294 \\
3.0 & - & - & 93 & 279 \\
3.2 & - & - & 98 & 294 \\
3.4 & - & - & 110 & 331 \\
3.6 & - & - & 123 & 368 \\
3.8 & - & - & 127 & 382 \\
4.0 & - & - & 147 & 441 \\
\hline & & & & \\
\hline
\end{tabular}

TABLE 5. Total estimated settlement obtained at different foundation depth and width.

\begin{tabular}{cccc}
\hline \multirow{2}{*}{$\begin{array}{c}\text { Foundation } \\
\text { width }(\mathrm{m})\end{array}$} & \multicolumn{3}{c}{ Settlement $(\mathrm{mm})$ at depth level $(\mathrm{m})$} \\
\cline { 2 - 4 } & $1 \mathrm{~m}$ & $2 \mathrm{~m}$ & $3 \mathrm{~m}$ \\
\hline 0.6 & 45.92 & 45.24 & 44.15 \\
1 & 30.05 & 30.44 & 30.06 \\
2 & 16.07 & 17.17 & 17.28 \\
3 & 10.7 & 11.96 & 12.2 \\
\hline
\end{tabular}

TABLE 6. Allowable and ultimate bearing capacity for strip and square shallow foundation.

\begin{tabular}{ccccc}
\hline \multirow{2}{*}{$\begin{array}{l}\text { Depth } \\
(\mathrm{m})\end{array}$} & Strip & Square & Strip & Square \\
\cline { 2 - 5 } & $\begin{array}{c}q_{\text {ultimate }} \\
\left(\mathrm{kN} / \mathrm{m}^{2}\right)\end{array}$ & $\begin{array}{c}q_{\text {ultimate }} \\
\left(\mathrm{kN} / \mathrm{m}^{2}\right)\end{array}$ & $\begin{array}{c}q_{\text {allowable }} \\
\left(\mathrm{kN} / \mathrm{m}^{2}\right)\end{array}$ & $\begin{array}{c}q_{\text {allowable }} \\
\left(\mathrm{kN} / \mathrm{m}^{2}\right)\end{array}$ \\
\hline 0.6 & 608 & 990 & 203 & 330 \\
1.0 & 882 & 1323 & 294 & 441 \\
1.4 & 2940 & 3822 & 980 & 1274 \\
\hline
\end{tabular}
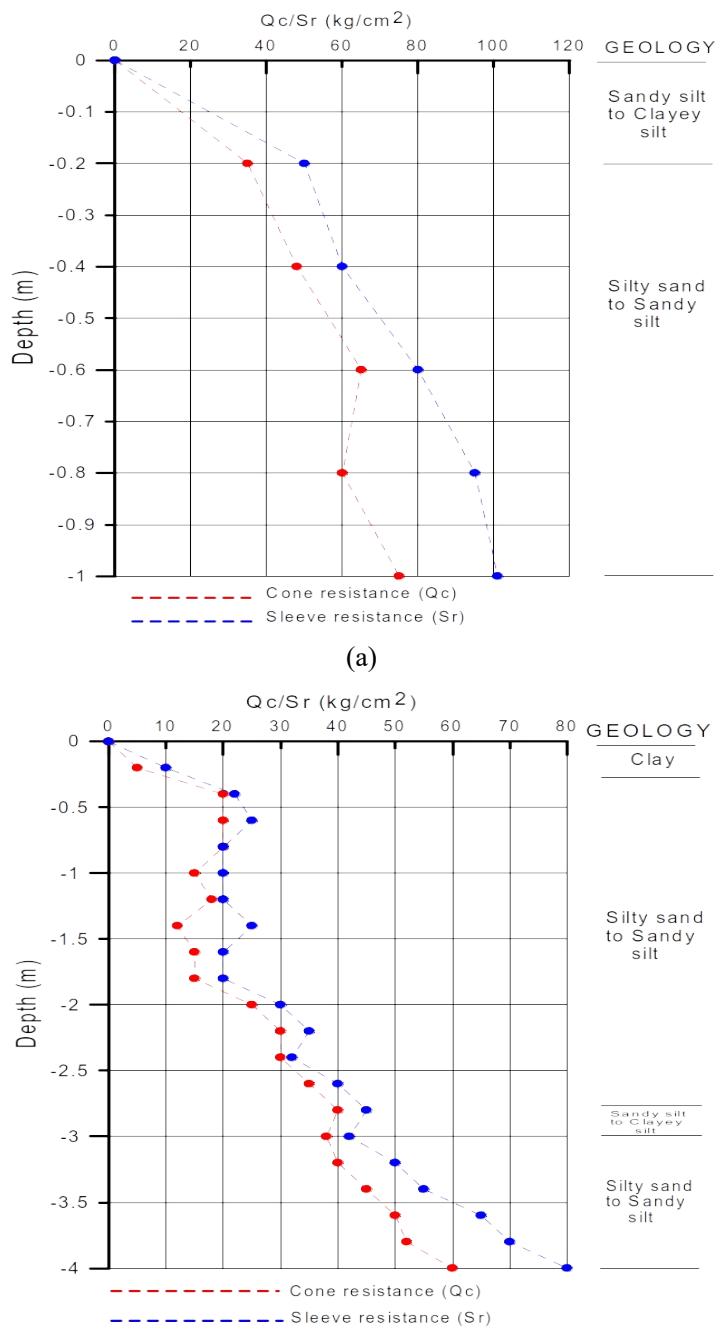

(b)

FIGURE 9. Plots of cone resistance and Sleeve friction against depths at (a) location 1 and (b) location 2.

installation of the pile (Tomlinson, 1999) in the study area to ensure these proposed design alternatives be effectively and correctly used.

\section{CONCLUSION}

Based on the resistivity parameters (242 - 1503 ohm-m), thickness $(3.4-20.9 \mathrm{~m})$ of the geoelectric layer of the topsoil, it is capable of hosting foundation structure within the upper $3 \mathrm{~m}$, with an allowable bearing capacity of $100 \mathrm{kN} / \mathrm{m}^{2}$ at $1.2 \mathrm{~m}$ at location 1 and $3.2 \mathrm{~m}$ at location 2. The soil within this unit was characterized with good geotechnical properties in conformity with the Federal Ministry of Works and the Housing specification of Nigeria. The estimated settlement was less than $50 \mathrm{~mm}$ using a foundation width of $0.6 \mathrm{~m}$ but could be reduced by 


\section{OLUSOLA}

TABLE 7. Ultimate and allowable bearing capacity of driven and bored piles of diameter $0.4 \mathrm{~m}, 0.5 \mathrm{~m}$, and $0.6 \mathrm{~m}$.

\begin{tabular}{|c|c|c|c|c|c|c|c|c|}
\hline \multirow{2}{*}{$\begin{array}{l}\text { Depth } \\
(\mathrm{m})\end{array}$} & \multirow{2}{*}{$\begin{array}{l}\text { Pile di- } \\
\text { ameter } \\
(\mathrm{m})\end{array}$} & \multirow{2}{*}{$\begin{array}{l}\text { End } \\
\text { bearing } \\
\text { capacity } \\
(\mathrm{KN})\end{array}$} & \multicolumn{3}{|c|}{ Driven Pile } & \multicolumn{3}{|c|}{ Bored Pile } \\
\hline & & & $\begin{array}{c}\text { Skin } \\
\text { Friction } \\
(\mathrm{KN})\end{array}$ & $\begin{array}{l}\text { Ultimate } \\
\text { pile } \\
\text { capacity } \\
(\mathrm{KN})\end{array}$ & $\begin{array}{l}\text { Allowable } \\
\text { pile } \\
\text { capacity } \\
(\mathrm{KN})\end{array}$ & $\begin{array}{l}\text { Skin } \\
\text { friction } \\
(\mathrm{KN})\end{array}$ & $\begin{array}{l}\text { Ultimate } \\
\text { pile } \\
\text { capacity } \\
(\mathrm{KN})\end{array}$ & $\begin{array}{l}\text { Allowable } \\
\text { pile } \\
\text { capacity } \\
(\mathrm{KN})\end{array}$ \\
\hline \multirow[t]{3}{*}{5} & 0.4 & 80 & 126 & 207 & 69 & 29 & 109 & 36 \\
\hline & 0.5 & 126 & 158 & 284 & 95 & 36 & 162 & 54 \\
\hline & 0.6 & 181 & 190 & 371 & 124 & 43 & 224 & 75 \\
\hline \multirow[t]{3}{*}{10} & 0.4 & 163 & 511 & 674 & 225 & 116 & 279 & 93 \\
\hline & 0.5 & 254 & 639 & 893 & 298 & 145 & 399 & 133 \\
\hline & 0.6 & 366 & 767 & 1133 & 378 & 174 & 540 & 180 \\
\hline \multirow[t]{3}{*}{15} & 0.4 & 247 & 1163 & 1409 & 470 & 264 & 511 & 170 \\
\hline & 0.5 & 385 & 1453 & 1839 & 613 & 330 & 716 & 239 \\
\hline & 0.6 & 555 & 1744 & 2299 & 766 & 396 & 951 & 317 \\
\hline
\end{tabular}

almost $50 \%$ if the width is greater than or equal to $2 \mathrm{~m}$. The groundwater level was deep and may not likely affect shallow foundation structures. In high rising buildings, strip and square footing could be adopted, with an estimated allowable bearing capacity ranging from $203-980$ $\mathrm{kN} / \mathrm{m}^{2}$ and $608-2940 \mathrm{kN} / \mathrm{m}^{2}$, respectively. In addition, driven pile (deep foundation) circular piles of diameters $400 \mathrm{~mm}, 500 \mathrm{~mm}$, and $600 \mathrm{~mm}$ are also recommended, with pile capacity varying at depths of $5 \mathrm{~m}(69-124 \mathrm{kN}), 10 \mathrm{~m}(225-$ $378 \mathrm{kN})$, and $15 \mathrm{~m}(470-766 \mathrm{kN})$. The capacity of the bored circular pile ranges from $(36-75$ $\mathrm{kN})$ at $5 \mathrm{~m}$ depth, $(93-180 \mathrm{kN})$ at $10 \mathrm{~m}$ depth, and $(170-317 \mathrm{kN})$ at $15 \mathrm{~m}$. These loading capacities were appropriate and recommended for building design. However, it should be noted that a pile load test must be conducted to corroborate and re-validate these design estimations. Therefore, both shallow and deep foundations are feasible, although they depend on the intended structural load.

\section{ACKNOWLEDGEMENTS}

Special appreciation to TETfund, Nigeria, through the Centre for Research and Development of Rufus Giwa Polytechnic, Owo, Ondo State, Nigeria, provides this research work.

\section{REFERENCES}

Adigun, M., Olatunji, K., Alaboru, F., and Ogunbajo, A. (2014) Evaluation of Sub-Soil Geotechnical Properties for Shallow Foundation and Pavement Design in LASPOTECH, Ikorodu Campus, Lagos State, Nigeria IOSR Journal of Mechanical and Civil Engineering (IOSR-JMCE) Volume 11, Issue 6, Ver. IV 40-47pp.

Akintorinwa, O.J., and Oluwole, S.T. (2018) Correlation of geotechnical parameters with geological formations in a basement complex and its implications on civil structure foundation. International Journal of Physical Sciences Vol. 13(9), pp. 147-162. Article Number: EC263EC57035, ISSN 1992-1950. DOI: 10.5897/IJPS2017.4681.

API (1984) Recommended practice for planning, designing, and constructing fixed offshore platforms, 15th ed.

ASTM (2006) Standard Practice for Classification of Soils for Engineering Purposes (Unified Soil Classification System).

Badmus, B.S., Akinyemi, O.D., Olowofela, J.A., Folarin, G.M. (2012) 3D electrical resistivity tomography survey for the basement of the Abeokuta terrain of Southwestern Nigeria. J. Geol. Soc. India 80, 845. DOI: 10.1007/s12594-012-0213-x.

Bell, FG (2007) Engineering Geology. Elsevier Ltd; ISBN: 978-81-312-1117-5

Bowles, J.E. (1988) Foundation Analysis and Design. McGraw-Hill Book Company, Singapore.

British Standard Institutions (1990) Methods of Test for soils for Civil Engineering Purposes. BS 1377: Part 2, pp 8- 200

Bustamante, M., and Gianeselli, L. (1982) Pile Bearing Capacity Predictions by Means of StaticPenetration CPT. Proceedings of 2nd European Symposium on Penetration Testing, Amsterdam.Vol. 2, 493-500.

CFEM (1992) Canadian Foundation Engineering Manual. Third Ed, Canadian Geotechnical Society, BiTech. Publishers, Vancouver, $512 \mathrm{p}$.

Coerts, A.O. (1996) Analysis of static cone penetration test data for subsurface modeling. A method- 
ology - Ph.D. Thesis, Nethernals Geographical Studies 210, 263pp

Coker, J.O., Makinde, V., Adesodun, J.K., and Mustapha, AO (2013) Integration of Geophysical and Geotechnical Investigation for a Proposed New Lecture Theatre at Federal University of Agriculture, Abeokuta, South-Western Nigeria. International Journal of Emerging Trends in Engineering and Development Issue 3, Vol.5: 338-348

Coker, JO (2015) Geophysical and Geotechnical Assessment of Foundation Failure: A Case Study of Library Complex Area, Lagos State Polytechnic, Ikorodu, Lagos, Nigeria. Research Journal in Engineering and Applied Sciences. Vol.3, No 7.

Das, B.M. (2004) Principles of Foundation Engineering 5th Edition. Brooks/Coe Publishing Co., California.

de Ruiter, J., and Beringen, F.L. (1979) Pile Foundations for Large North Sea Structures. Marine Geotechnology, Vol. 3, No. 3, pp. 267-314.

Debeer, EE (1963) The scale effect in the transposition of the results of deep sounding tests on the ultimate bearing capacity of piles and caisson foundations. Geotechnique, Vol. 13, No. 1, pp.39-75.

FMWH (1972) Highway Manual Part 1 Road Design, Federal Ministry of Works and Housing, Lagos.

Ibitoye, F.P, Ipinmoroti, F.V., Salami, M., Akinluwade, K.J., Adeyinka T.T, Adetunji A.R. (2013) Application of Geophysical Methods to Building Foundation Studies, International Journal of Geosciences, 2013, 4, 1256-1266. DOI: 10.4236/ijg.2013.49120.

Iloeje, M. P. (1981) A new Geography of Nigeria. Longman Nigeria, 26 - 28.

Jegede, G. (2000) Effect of soil properties on pavement failure along the F209 highway at Ado-Ekiti, Southwestern Nigeria. Journal of Construction and Building Materials, vol. 14, pp. 311-315.

Jones, H.A., and Hockey, RD (1964) The Geology of part of Southwestern Nigeria, Geological Survey Nigeria Bulletin, 31: 56 - 86.

Koefeod, O. (1979) Geosounding principles, I. Resistivity sounding measurements, Elsevier Scientific Publishing Comp, Amsterdam, 275p.

Lunne, T., Robertson, P.K., and Powell, J.J.M. (1997) Cone Penetration Testing in Geotechnical Practise, Blackie Academic and Professional, London, 312p.

Mazlan, A. (2007) Correlation Between Cone Penetration Test and Bearing Capacity for ShallowFoundation. Master's Thesis. Universiti Teknologi Malaysia.

Meyerhof, G.G. (1976) Bearing capacity and settlement of ASCE, Journal of Geotechnical Engineering, Vol. 102, GT3, pp. 195 - 228.

Murthy, V.N.S. (2002) Principles and Practices of Soil
Mechanics and Foundation Engineering. CRC Press, Florida.

Ngah, S.A., and Nwankwoala, H.O. (2013) Evaluation of Sub-Soil Geotechnical Properties for Shallow Foundation Design in Onne, Rivers State, Nigeria. The International Journal of Engineering and Science (IJES), Volume 2, Issue 11, Pages 0816.

Nottingham, L.C., (1975) Use of quasi-static friction cone penetrometer data to predict load capacity of displacement piles. Ph.D. Thesis, Dept. of Civil Engineering., University of Florida, 553p.

Nwankwoala, H.O., and Amadi, AN (2013) Geotechnical Investigation of Sub-soil and Rock Characteristics in parts of Shiroro- MuyaChanchaga Area of Niger State, Nigeria. International Journal of Earth Sciences and Engineering, Vol. 61: 8 -17.

Nwankwoala, H.O., and Warmate, T. (2014) Geotechnical Assessment of Foundation Conditions of a Site in Ubima, Ikwerre Local Government Area, Rivers State, Nigeria. International Journal of Engineering Research and Development (IJERD), 98: 50 - 63.

Okosun, E.A. (1998) Review of the Early Stratigraphy of Southwestern Nigeria, Journal of Mining and Geology, 34 (1), 27 - 35.

Omatsola, M.E., and Adegoke, O.S. (1981) Tectonic Evolution and Cretaceous Stratigraphy of the Dahomey Basin, Journal of Mining and Geology, 8: 30-137.

Omosuyi, G.O. (2001) Geophysical and Hydrogeological Investigations of Groundwater Prospects in the Southern Part of Ondo State, Nigeria. Ph.D. Thesis, Department of Applied Geophysics, Federal University of Technology, Akure, Nigeria.195pp.

Omosuyi, G.O., Ojo, JS, and Olorunfemi, M.O. (2007) Hydrochemical Investigation of Groundwater in Okitipupa area, Ondo State, Southwestern Nigeria. Journal of African Water Resources and Environment (Aquaterra), 1(2), 3 - 13.

Osinowo O.O., Falufosi M.O. (2018) 3D Electrical Resistivity Imaging (ERI) for subsurface evaluation in pre-engineering construction site investigation NRIAG Journal of Astronomy and geophysics (2018). DOI: 10.1016/j.nrjag.2018.07.001.

Osinowo, O.O., Akanji, A.O., Akinmosin, A. (2011) Integrated geophysical and geotechnical investigation of the failed portion of a road in Basement Complex terrain, southwestern Nigeria. RMZ Mater. Geoenviron. 58 (2), 143-162.

Owamah, H.I., Atipko, E., Ukala, D.C, and Apkan, E.J. (2018) Assessment of Some Geotechnical Properties of Nigerian Coastal Soil: A CaseStudy of Port-Harcourt Beach Mud. Appl. Sci. 
Environ. Manage. Vol. 22 (2) 228 - 233. DOI: 10.4314/jasem.v22i2.13.

Oyedele, K.F., Oladele, S., and Adedoyin, O. (2011) Application of Geophysical and Geotechnical Methods to Site Characterization for Construction Purposes at Ikoyi, Lagos, Nigeria Journal of Earth Sciences and Geotechnical Engineering, 1(1): $87-100$.

Robertson, P.K. (1990) Soil classification using the cone penetration test. Canadian Geotechnical Journal, 27:151-158.

Sanglerat, G. (1972) The Penetrometer and Soil Exploration. Elsevier Publishing Co., Amsterdam.

Schmertmann, J.H. (1970) Static cone to compute static settlement over-sand. Journal of the Soil Mechanics and Foundations Division. ASCE. Vol. 96. No. SM3. Proc. Paper 7302, pp. 1011 - 1043.

Schmertmann, J.H. (1978) Guidelines for Cone Penetration Test: Performance and Design. U.S.Dept. of Transportation, Washington, DC.

Skempton, A.W. (1951) The Bearing Capacity of Clays, Proceedings Building Research Congress, Vol. 1, pp. 180-189.
Stroud, M.A., and Butler, F.G. (1975) The standard penetration test and the engineering properties of Glacial materials. In: Proceedings of the Symposium of glacial materials, University of Birmingham.

Sudha, K., Israil, M., Mittal, S., Rai, J. (2009) Soil characterization using electrical resistivity tomography and geotechnical investigations. Journal of Applied Geophysics, 67, 74-79.

Telford, W.M., Geldart, L.P., Sheriff, RE (1990) Applied Geophysics, second edition. Cambridge University Press.

Terzaghi, K., and Peck, R. B. (1967) Soil Mechanics in Engineering Practice, John Wiley \& Sons, Inc., 2nd edition, New York, p. 491.

Tomlinson M.J. (1999) Foundation Design and Construction 6th Edition.

Webb, D.L. (1969) Settlement of Structures on deep alluvial sand sediments in Durban, South Africa, British Geotechnical Society Conference on in-Situ Investigations in Soils and Rocks, Session III, paper 16, London, England, 13-15 May 1969, pp. 133-140. 